\title{
Implementasi Aplikasi Keberangkatan Pelaut Berbasis Web Menggunakan Metode AHP (Analytic Hierarchy Process)
}

\author{
Teguh Triatmojo ${ }^{1^{*}}$, Muhammad Rifqi ${ }^{2}$ \\ 1) 2)Program Studi Informatika, Fakultas Ilmu Komputer, Universitas Mercu Buana \\ Jl. Meruya Selatan No.1 Kembangan, Jakarta, Indonesia 11650 \\ *E-mail:141516120019@student.mercubuana.ac.id,2m.rifqi@mercubuana.ac.id
}

(Naskah masuk: tgl. 15 April 2021; diterima untuk diterbitkan: 30 Juli 2021)

\begin{abstract}
ABSTRAK - Riset ini menelaah tentang penentuan keberangkatan pelaut terbaik, proses penentuan keberangkatan pelaut merupakan permasalahan yang melibatkan banyak kriteria dan alternatif yang dinilai, sehingga dalam penyelesaiannya diperlukan sistem pendukung keputusan. Proses penentuan keberangkatan pelaut pada Fast Offshore Supply, masih terkendala karena belum ada metode yang efektif dan kriteria penilaian hanya bersadarkan pada panggilan telepon genggam ataupun telepon seluler. Tujuan adanya aplikasi berbasis web ini adalah dapat memudahkan pelaut dalam menentukan keberangkatan mulai dari tanggal berangkat, tanggal berakhir dan sejenisnya secara lebih efektif dan efisien serta meringankan laporan pekerjaan para pelaut yang awalnya bersifat manual, menjadi serba digital. Peneliti memulai pemeriksaan dengan mengumpulkan informasi, lebih spesifik dengan studi menulis dan bertemu dengan Assistant Manager untuk mengidentifikasikan masalah. Analytic Hierarchy Process (AHP) adalah sistem penunjang keputusan untuk mencari tahu opsi yang dipakai dalam alternatif dan kriteria dari beberapa perbandingan kriteria tersebut. Diharapkan dengan adanya pembobotan dari metode AHP (analytic hierarchy process) ini bisa teratasi masalah dengan pemilihan calon pelaut yang akan diberangkatkan. Dari hasil perhitungan AHP didapatkan 4 kriteria dengan 4 alternatif dan diperoleh 4 urutan nilai tertinggi, yaitu Luther dengan $1 \%$, Mujafar dengan 0,564\%, Musakkir dengan 0,223\%, Upi dengan $0,213 \%$.
\end{abstract}

Kata Kunci: Sistem Informasi; AHP; Web; Laporan; Efektif; Efisien

\section{Implementation of a Web-Based Seafarers Departure Application Using the AHP (Analytic Hierarchy Process) Method}

\begin{abstract}
This research examines the determination of the best seafarers' departure, the process of determining the departure of seafarers is a problem that involves many criteria and alternatives being assessed, so that in its completion a decision support system is needed. The process of determining the departure of seafarers in Fast Offshore Supply is still constrained because there is no effective method and the assessment criteria are only based on cell phone calls or cell phones. The purpose of this web-based application is to make it easier for seafarers to determine departure starting from the departure date, end date and the like more effectively and efficiently and to ease seafarers' work reports, which were originally manual, to all digital. The researcher started the examination by gathering information, more specifically by writing study and meeting with the Assistant Manager to identify the problem. Analytic Hierarchy Process (AHP) is a decision support system to find out the options used in the alternatives and the criteria from several comparisons of these criteria. It is hoped that with the weighting of the AHP (analytic hierarchy process) method this problem can be resolved with the selection of prospective sailors to be dispatched. From the results of the AHP calculation, there are 4 criteria with 4 alternatives and the 4 highest order values are obtained, namely Luther with $1 \%$, Mujafar with $0.564 \%$, Musakkir with $0.223 \%$, Upi with $0.213 \%$
\end{abstract}

Keywords - Information Systems; AHP; Web; Report; Effective; Efficient 


\section{Pendahuluan}

Peningkatan kerangka data hari ini telah menunjukkan keajaiban yang menarik. Berbagai bidang pengajaran, organisasi pemerintah, dan banyak lainnya menggunakan inovasi dan kreasi dari ilmu pengetahuan dan teknologi. Untuk itu peneliti membuat aplikasi keberangkatan pelaut berbasis web dengan menggunakan metode AHP. Bagi Novrisal, Almira and Febrianty, (2019) AHP (analytic hierarchy process) merupakan suatu metode pendukung keputusan yang dikembangkan oleh seorang ahli matematika University of Pittsburgh kelahiran Irak, Thomas L. Saaty, kontribusi yang diharapkan dengan adanya aplikasi ini dapat memudahkan awak kapal dalam menentukan keberangkatan mulai dari tanggal berangkat, tanggal berakhir dan sejenisnya secara lebih efektif dan efisien serta meringankan laporan pekerjaan para pelaut yang awalnya bersifat manual, menjadi ke komputerisasi. [1].

Bagi Pramono, Fahrianto and Sc, (2019) data ialah salah satu peninggalan berarti untuk keberlangsungan hidup sehingga wajib dilindungi, diupdate, dan dibackup dalam pertahanan serta keamanan diawali dari organisasi yang terkecil, menengah, hingga ke ranah Pemerintahan, dan dalam sistem pembelian serta penjualan antar konsumen, sehingga wajib dilindungi ketersediaan, ketepatan serta keutuhan. [2] Permasalahan ada dalam departemen pelaut Fast Offshore Supply diantaranya yaitu standar kontrak kerja pelaut Fast Offshore Supply rata-rata, 3-6 bulan di laut dan 1 bulan di darat. Kemudian pelaut cuti di darat mereka juga diberikan laporan pekerjaan, dan juga laporan pekerjaan masih bersifat manual untuk Fast Offshore Supply, sehingga peneliti menetapkan level dari masing-masing pelaut dalam menentukan keberangkatan pelaut menggunakan AHP.

Dalam penentuan keberangkatan pelaut sekarang ini masih mengandalkan komunikasi melalui panggilan telepon genggam atau telepon seluler. Kemudian banyak faktor yang mempengaruhi cepat atau lambat pelaut dalam keberangkatannya. Dalam beberapa dekade terakhir ini belum ada aplikasi dalam menentukan keberangkatan seorang pelaut yang mengarah pada bagian pelaut tentang tanggal berangkat, tanggal berakhir dan sejenisnya. Untuk itu peneliti bermaksud membuat aplikasi keberangkatan pelaut berbasis web menggunakan metode AHP (analytic hierarchy process).

Berdasarkan masalah di atas, maka akan dilakukan riset tentang bagaimana merancang sebuah aplikasi berbasis web untuk penentuan seorang pelaut dalam keberangkatannya dan keadaan darurat yang lain, untuk menentukan tanggal berangkat dan tanggal berakhir, bagi Bintoro et al., (2018) sebelumnya terdapat banyak penelitian yang terjadinya suatu aplikasi yang informatif dalam memberikan keputusan mengenai algoritma yaitu diimplementasikan dengan Algorithma AHP (analytical hierarchy process). [3] Dari beberapa jurnal yang telah peneliti pelajari metode keputusan AHP cocok dengan dataset yang telah didapat serta bagi Rifqi and Wardhani, (2017) mengakumulasi referensi dalam peneliti disini menghubungkan artikel atau karya ilmiah dari kasus terebut. [4]

Beberapa kajian literatur terdahulu ialah sebagai berikut : penelitian sebelumnya $\mathrm{R}$ Laisouw, Lutfi and Tempola, (2019) dengan sistem pendukung keputusan pemberian bantuan program keluarga harapan (pkh) di kota ternate menggunakan metode AHP [5], Bagi Agustini, (2018) penerapan metode AHP pada pemilihan kosmetik pada siswi SMA [6], Bagi Rachman, (2019) penerapan metode AHP untuk menentukan kualitas pakaian jadi di industri garment [7], Azhar and Handayani, (2018) analisis faktor prioritas dalam memilih $\mathrm{kpr}$ menggunakan metode AHP [8], Laurentinus and Rinaldi, (2019) implementasi metode AHP dan SAW untuk memilih dosen terbaik [9], Nasution, (2017) menentukan tingkat kemacetan lalu lintas dengan metode AHP [10], Arisusanty et al., (2018) analisa menentukan kriteria pelabuhan tol laut dengan menggunakan metode AHP [11], Salim and Lubis, (2019) pemilihan merek beras dengan menggunakan metode AHP [12], Azza and Dores, (2018) sistem informasi manajemen marketing tools dengan metode AHP. [13]

Tujuan dibuat aplikasi keberangkatan pelaut ini adalah mengimplementasikan algoritma AHP (Analytic Hierarchy Process), untuk menentukan keputusan apakah diterima maupun tidak dalam keberangkatan pelaut dalam Fast Offshore Supply, merancang aplikasi untuk pelaut berbasis web yang berguna untuk mempermudah pelaut dalam memberikan laporan pekerjaan yang awalnya bersifat manual, menjadi ke komputerisasi. Dengan kata lain dapat mempermudah pelaut dalam melaporkan laporan pekerjaan dengan menggunakan Algoritma AHP, serta dapat menentukan tanggal berangkat dan tanggal berakhir dari pelaut tersebut. Manfaat dalam penelitian ini diharapkan dapat meningkatkan keterluasan didalam aplikasi tersebut, sistem informasi yang diberikan cukup akurat dan aman serta waktu menjadi lebih efektif dan efisien.

Dari permasalahan di atas, maka peneliti ingin memperbaharui data kriteria, sub kriteria, dan alternatif melalui penilaian level dari masing-masing pelaut yang lebih akurat dan terukur dengan menggunakan metode AHP (analytical hierarchy process) dan dataset diperoleh dari Departemen Pelaut Fast Offshore Supply yang dilakukan dengan cara 
membandingkan kepentingan level dari kriteria dan sub kriteria tersebut.

\section{METODE DAN BAHAN}

\section{Metode Pengumpulan Data}

Dalam pengujian, peneliti menggunakan strategi eksplorasi subjektif, mengingat dalam mengumpulkan informasi peneliti perlu menyebutkan fakta objektif dan pertemuan terhadap narasumber yaitu Assistant Manager di Fast Offshore Supply Jakarta Barat. Dari pertemuan tersebut peneliti mendapatkan keterangan dalam memperoleh data tentang pelaut seperti pada tabel.1.

Tabel.1 Data Pelaut Fast Offshore Supply

\begin{tabular}{|c|c|c|c|c|c|c|}
\hline $\begin{array}{l}\mathbf{n} \\
\mathbf{o}\end{array}$ & $\begin{array}{l}\text { na } \\
\text { ma }\end{array}$ & rank & $\begin{array}{l}\text { date } \\
\text { onboar } \\
d\end{array}$ & $\begin{array}{l}\text { due } \\
\text { date } \\
\text { onboar } \\
d\end{array}$ & $\begin{array}{l}\text { days } \\
\text { onboa } \\
\text { rd }\end{array}$ & $\begin{array}{l}\text { over } \\
\text { due } \\
\text { onboa } \\
\text { rd }\end{array}$ \\
\hline 1 & $\begin{array}{l}\text { yad } \\
\mathrm{i}\end{array}$ & $\begin{array}{l}\text { mast } \\
\text { er }\end{array}$ & $\begin{array}{l}08 / 01 / \\
20\end{array}$ & $\begin{array}{l}07 / 04 / \\
20\end{array}$ & 360 & 270 \\
\hline 2 & $\begin{array}{l}\text { sup } \\
\text { ri }\end{array}$ & $\begin{array}{l}\text { mast } \\
\text { er }\end{array}$ & $\begin{array}{l}21 / 01 / \\
20\end{array}$ & $\begin{array}{l}20 / 04 / \\
20\end{array}$ & 347 & 257 \\
\hline 3 & ade & $\mathrm{CO}$ & $\begin{array}{l}26 / 12 / \\
20\end{array}$ & $\begin{array}{l}25 / 03 / \\
20\end{array}$ & 373 & 283 \\
\hline 4 & aris & 20 & $\begin{array}{l}01 / 02 / \\
20\end{array}$ & $\begin{array}{l}01 / 05 / \\
20\end{array}$ & 336 & 246 \\
\hline 5 & $\begin{array}{l}\text { ant } \\
\mathrm{o}\end{array}$ & ce & $\begin{array}{l}12 / 01 / \\
20\end{array}$ & $\begin{array}{l}11 / 04 / \\
20\end{array}$ & 356 & 266 \\
\hline
\end{tabular}

Berikut ini penjelasan masing-masing dari tabel tersebut.

a. Nama merupakan identitas utama yang diberikan ketika mendata awal dari pelaut tersebut.

b. Rank merupakan pangkat atau jabatan ketika dia bekerja di laut mulai dari Master, $\mathrm{CH}$ Engineer sampai dengan Cook.

c. Date Onboard merupakan tanggal keberangkatan pelaut untuk bekerja di laut.

d. Due Date Onboard (90 days) merupakan batas waktu selama 90 hari yang diberikan ketika seorang pelaut bekerja di kapal.

e. Days Onboard merupakan waktu yang sudah $O K$ ketika dia berada di kapal.

f. Over Due Onboard merupakan batas waktu yang melebihi dari kontrak awal perjanjian kerja laut ketika berada di kapal.

\section{Metode Pengembangan Sistem}

Riset ini menggunakan kategorisasi dalam Extreme Programming (XP) untuk penerapan keberangkatan pelaut. Bagi Pertiwi, (2018) dalam riset ini tingkatan penambahan simplifikasi dengan beraneka ragam cara Extreme Programming (XP) ialah bentuk keterangan menjadi lebih efektif, luwes, dan elastis. [14] Gambar 1 adalah 4 langkah dalam extreme programming diantaranya adalah Planning, Design, Coding dan Testing.

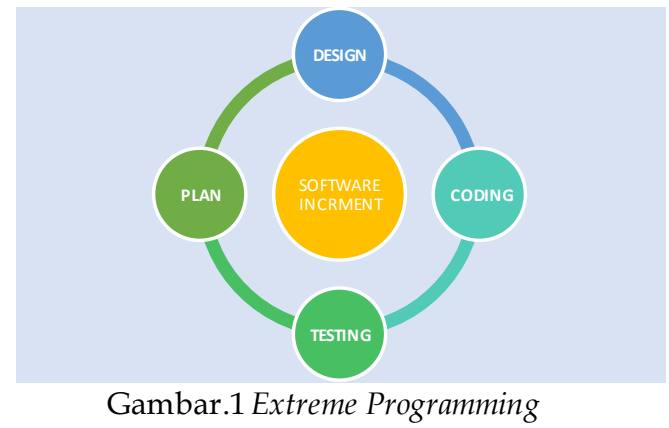

Teknik Extreme Programming (XP) dari empat fase yang harus dilakukan adalah:

1. Identifikasi kebutuhan Pemakai (planning) : Pada tahap ini mengumpulkan masalah yang ada dalam Fast Offshore Supply dan mencari solusi yang dibutuhkan oleh Departemen Pelaut.

2. Penyusunan rancangan (design) ialah memperoleh bahan dari beraneka ragam referensi, sesudah itu membuat indikator dari fakta yang akan ditelaah dan juga pembentukan kerangka dalam bentuk mockup.

3. Pengkodean metode (coding) ialah melaksanakan bagian pengolah aplikasi melalui alur bisnis dari pengenalan kepentingan pengguna dan penyusunan rancangan.

4. Pengujian sistem (testing) ialah sesudah dibuat dengan perancangan, kemudian melaksanakan pengecekan ulang.

\section{Algoritma AHP}

Thomas L. Saaty ialah orang yang pertama kali melahirkan suatu cara penunjang keputusan dalam memilah suatu alternatif yang berasal dari University of Pittsburgh kelahiran Irak. Paradigma parameter ganda diperoleh dari cara Analytical Hierarchy Process (AHP) dengan jenis parameter dan penunjukan pengutamaan parameter tersebut Rosiska (2018) dan bagi Ruiz Rondan et al., (2020) ini dipakai untuk menentukan ukuran dari masing-masing skala berpasangan dan terus-menerus. [15] [16] Biasanya AHP mempunyai empat prosedur awal bagi Lin and Kou, (2020) yaitu acuan, perkiraan, kategorisasi utama dan sintesis. [17] Abdul Rojak and Rifai, (2018) hakikat alternatif itu memilah untuk menentukan suatu ketetapan. [18] Kriteria itu merupakan faktor umum yang menentukan penilaian dalam mengambil keputusan untuk keberangkatan pelaut. Bagi Unver and Ergenc, (2020) kriteria itu bergantung pada sudut pandang dan pengalaman individu. [19] Spesialis memiliki batasan secara umum tentang pencarian yang sesuai dengan substansi keputusan. Dalam mendapatkan kepastian tanggal berangkat, tanggal berakhir dan lain sebagainya tergantung 
pada satu keputusan dan itu akan menjadi apa saja kecuali tersebut lebih dari satu, dimungkinkan akan kesulitan untuk memilih, akan tetapi jika alternatif pilihan lebih dari satu, kita berkelebihan dalam hal memutuskannya.

Saaty AHP menyatakan, ini adalah kerangka pilihan yang menjelaskan berbagai jenis masalah yang tanpa cacat ke dalam klasifikasi. Bagi Ariani, (2017) alternatif diperoleh dari tingkat awal merupakan tujuan, yang diiringi bagian, parameter, sub parameter, serta penyampaian hierarki dari persoalan yang utuh dan seterusnya ke dasarsampai tingkat terakhir. [20] Dalam AHP, kategori pilihan bertemu contohnya pada permainan sepak bola pada separuh pertandingan. Diantara kekurangan AHP, yaitu tidak inkonsisten dalam pemberian kualitas jika berbagai macam jenisnya lebih dari satu. Untuk hasil yang menggunakan ukuran korelasi 1-9 Saaty seperti yang terlihat pada tabel 2 .

\begin{tabular}{l}
$\frac{\text { Tabel.2 Hipotesis Saaty }}{\text { ukuran }}$ \\
\hline 1 signifikan serupa \\
3 agak lebih signifikan \\
5 lebih signifikan \\
9 signifikansi langsung \\
2,4,6,8 rata-rata \\
\hline
\end{tabular}

Bagi Rohandi, Tuloli and Jassin, (2017) tingkatan 0 merupakan tujuan yang akan dibandingkan, sedangkan tingkatan 1 adalah beberapa kriteria yang terdiri atas alternatif yang lebih dari satu. [21]

Lalu untuk perhitungan LambdaMax seperti ini:

$$
C I=\frac{(\kappa \max -n)}{(n-1)}
$$

LambdaMax itu adalah rata-rata dari CM (Consistency Measure), $\mathrm{n}$ adalah jumlah kriteria (ukuran matriks), sehingga didapat skala random seperti pada tabel 3 .

Tabel.3Skala Random

\begin{tabular}{llllllccccc}
\hline $\mathrm{n}$ & 1 & 2 & 3 & 4 & 5 & 6 & 7 & 8 & 9 & 10 \\
$\mathrm{R} 1$ & 0 & 0 & 0.58 & 0.9 & 1.12 & 1.24 & 1.32 & 1.41 & 1.45 & 1.49 \\
\hline
\end{tabular}

Pada Tabel.3 diatas skala random didapatkan dengan nilai ordo matriks atau jumlah dari beberapa kriteria dan alternatif yang digunakan. Kemudian didapat:

$$
C R=C I / R I
$$

Jika CI = 0, maka perkembangannya stabil, Jika CR $<0.1$, maka rantai kepentingan tersebut benar-benar dapat diprediksi, Jika CR> 0.1, maka urutan rantai kepentingan sangat bertentangan.
Langkah-langkah yang dibuat dalam diagram penelitian ditunjukkan pada gambar 2 .

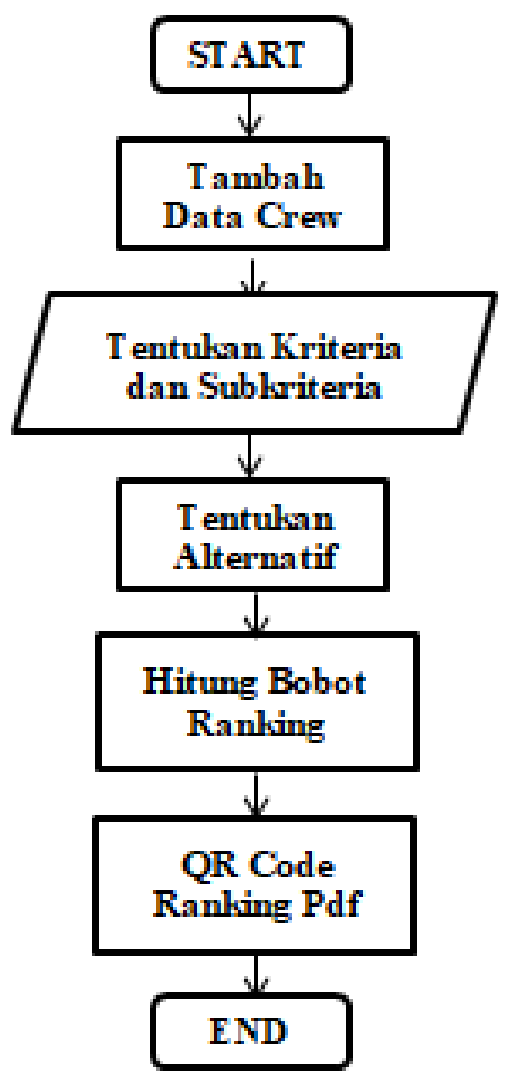

Gambar.2 Diagram Alir

Tahapan yang dilakukan dalam diagram penelitian ini adalah mulai dari menu User pilih Crew kemudian tambahkan data baru, pilih kriteria dan sub kriterianya. Bila sudah sesuai akan muncul alternatif dari pembanding tersebut lalu akan tersedia bobot rangkingnya dalam bentuk scan $Q R$ Code dan PDF

\section{Hasil dan PEMbahasan}

\section{UML (Unified Modelling Language)}

Bagi Suendri, (2018) UML ialah bahasa umum perancangan dari design entitas mengarah pada visualisasi lukisan dengan cara uraian. [22] "Unified Modeling Language (UML) dijadikan bahasa standar bentuk dalam gambar untuk memvisualisasikan dengan metodologi analisis dan design berorientasi objek. Ada delapan bagian dalam UML diagram, tetapi peneliti disini hanya memakai tiga dari diagram tersebut,

\section{Use Case}

Bagi Rachman, (2018) use case diagram ialah proses korelasi ditunjukkan antara user dengan sistem tersebut. [23] Bentuk interaksi pemakai terhadap suatu cara dapat dilihat pada gambar 3 .:

\section{Diagram Alir Penelitian.}




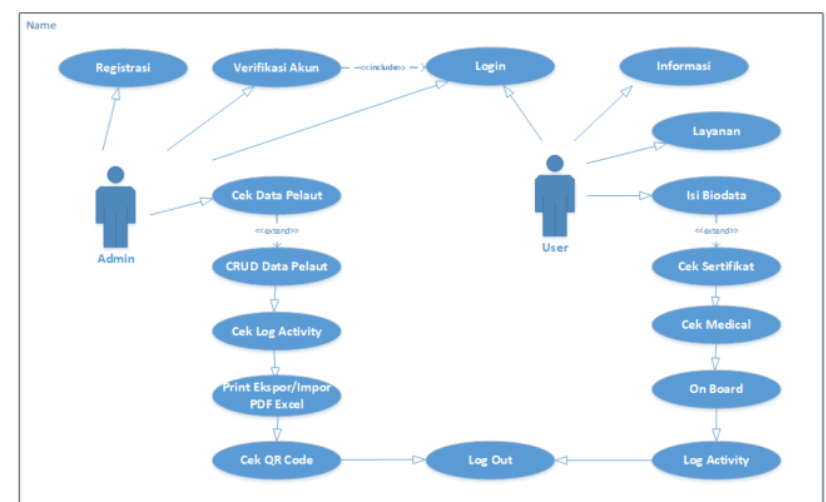

Gambar.3 Use case Diagram.

\section{User:}

a. Isi Biodata merupakan pembaharuan data yang diberikan oleh Admin terdiri dari id_pelaut, nama_pelaut, nomer telepon dan email.

b. Cek Sertifikat merupakan update data dari sertifikasi yang masih aktif atau sudah expited, ini adalah keharusan dan wajib bilamana seorang pelaut ingin berangkat atau sejenisnya.

c. Cek Medical merupakan kegiatan pemeriksaan fisik dalam menentukan apakah seorang pelaut tersebut sehat atau tidak untuk lanjut ke tahap berikutnya.

d. On board merupakan sudah $O K$ dari setiap dokumen dan segala persyaratan lainnya dan siap untuk berangkat dalam menjalankan tugasnya.

Admin:

a. Melihat seluruh data pelaut merupakan dapat dilakukan dengan access level dari setiap daily activity tersebut.

b. Print ekspor impor pdf / excel merupakan kegiatan dalam menerbitkan hasil rangking dalam setiap level pelaut.

c. Print qr code merupakan kegiatan dalam menerbitkan barcode dari hasil rangking tersebut

\section{Sequence.}

Bagi Prasetyaningrum, (2018) alur mekanisme sequence diagram menerangkan bagian use case yang telah dikerjakan. [24]

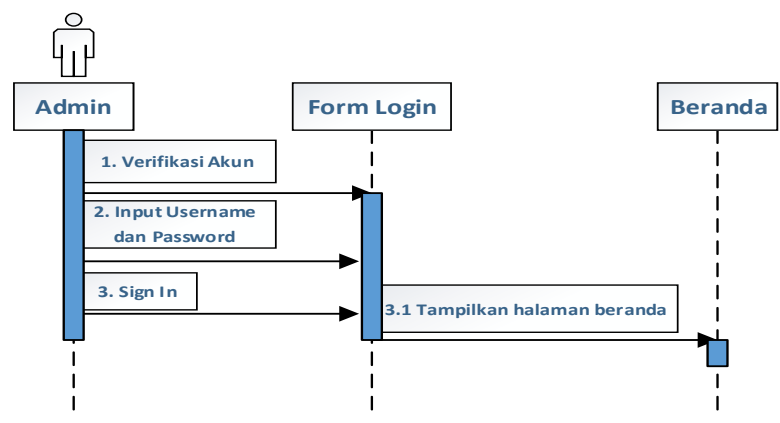

Gambar.4 Sequence Diagram untuk Login

Pada gambar.4 terdapat halaman login, controller, dan halaman beranda. Dimulai dari verifikasi akun jika belum terdaftar di sistemnya, masukkan username dan password lalu sign in serta menampilkan halaman utama dari beranda tersebut.

\section{Activity}

Bagi Bathin and Ramayanti, (2019) representasi activity diagram pada sebuah konsep ditunjukkan dari pola dalam sebuah metode. [25]. Gambar 5 menunjukkan activity diagram.

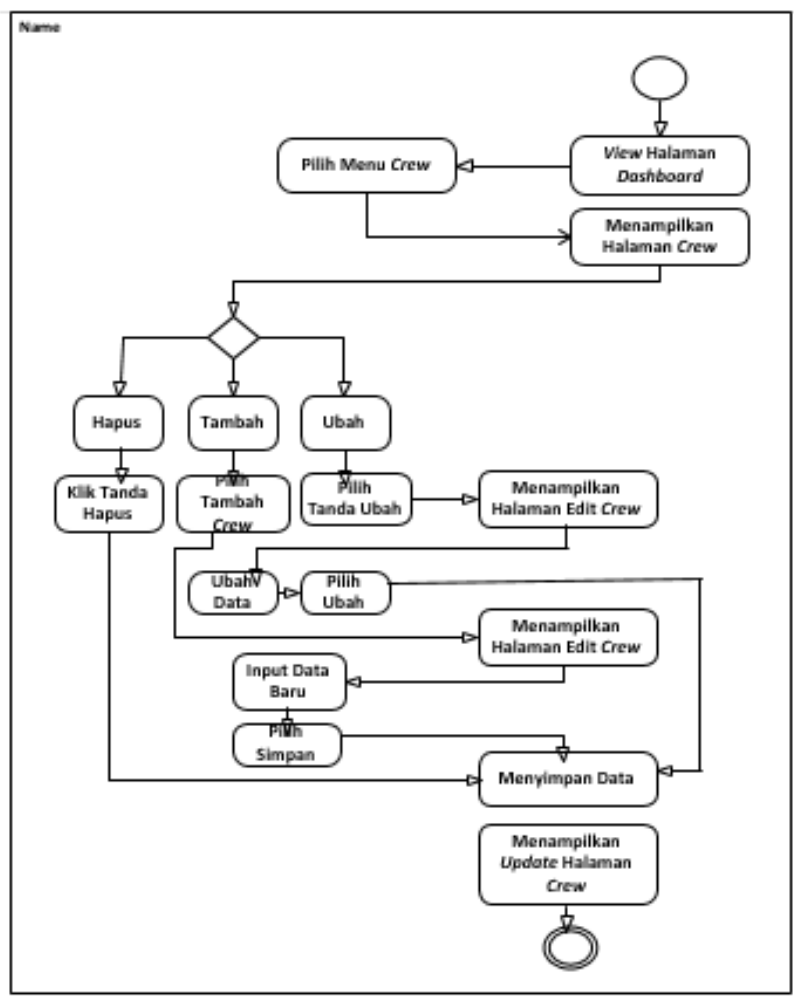

Gambar.5 Activity Diagram pada Menu Crew

Disini terdapat dua fungsi yaitu user sebagai pengguna dan web atau aplikasi. Tahap awal pengguna login dengan membuka web tersebut lalu web akan menampilkan menu Crew. Kemudian pengguna memilih data crew dan web otomatis akan menampilkan datanya. Terdapat pilihan yaitu pencarian istilah hapus, tambah, dan ubah kemudian web akan menampilkan data tersebut. Setelah 
semuanya terpenuhi dengan baik data tersebut akan langsung disimpan dalam database.

\section{Tahapan AHP}

Langkah-langkah dalam menentukan AHP adalah sebagai berikut :

1. Mendefinisikan masalah dan menentukan solusi yang diinginkan

- Tujuan : Keberangkatan Pelaut

- Kriteria : Rotasi, Medical, Sertifikasi

- Alternatif : 1 Bulan, 3 Bulan, 6 Bulan

2 Membuat struktur hierarki yang diawali dengan tujuan utama seperti pada gambar 6 .

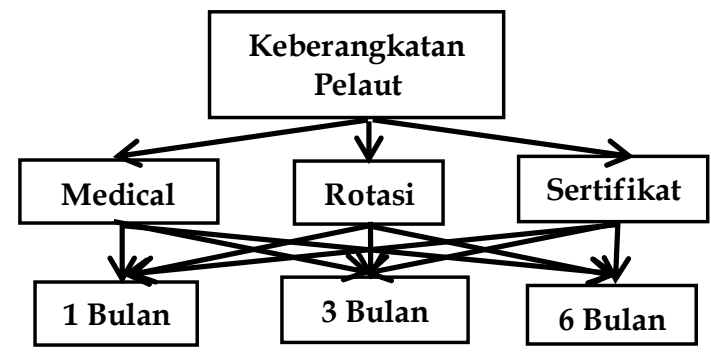

Gambar.6Struktur Hierarki

Dalam menentukan keberangkatan pelaut terdiri dari 3 kriteria yaitu medical, rotasi, dan sertifikat kemudian dengan 3 alternatif yaitu : 1 bulan, 3 bulan dan 6 bulan.

3 Membuat matrik perbandingan berpasangan.

\begin{tabular}{llll}
\multicolumn{4}{c}{ Tabel.4 Kriteria } \\
\hline kriteria & tujuan & bobot & aksi \\
\hline medical & 1 & 3 & 0,200 \\
medical & 0,333 & 1 & 1,43 \\
sertifikasi & 5,000 & 7,000 & 1 \\
\hline
\end{tabular}

Pada tabel 4, matrik perbandingan berpasangan dari beberapa kriteria yang menggambarkan kontribusi relatif atau pengaruh setiap elemen terhadap tujuan atau kriteria yang setingkat di atasnya.

4 Menghitung nilai eigen, vektor eigen dan menguji konsistensinya.

\begin{tabular}{lllll}
\multicolumn{4}{c}{ Tabel.5 Eigen \& Vektor Eigen } \\
\hline & $\begin{array}{l}\text { nilai } \\
\text { eigen }\end{array}$ & $\begin{array}{l}\text { jumlah } \\
\text { baris }\end{array}$ & $\begin{array}{l}\text { rata- } \\
\text { rata }\end{array}$ \\
\hline 0,15789 & 0,27272 & 0,14893 & 0,57955 & 0,19318 \\
47 & 73 & 62 & 82 & 61 \\
0,05263 & 0,09090 & 0,10638 & 0,24992 & 0,08330 \\
16 & 91 & 3 & 36 & 79 \\
0,78947 & 0,63636 & 0,74468 & 2,17051 & 0,72350 \\
37 & 36 & 09 & 82 & 61 \\
\hline
\end{tabular}

Pada tabel 5 terdapat nilai eigen dan menguji konsistensinya. Jika tidak konsisten maka pengambilan data diulangi. Lalu didapatkan nilai vektor eigen dari setiap matrik perbandingan berpasangan yang merupakan bobot setiap elemen untuk penentuan prioritas elemen-elemen pada tingkat hierarki terendah sampai mencapai tujuan.

5. Memeriksa konsistensi indeks dan konsistensi rasio hierarki.

\begin{tabular}{|c|c|c|}
\hline \multicolumn{3}{|c|}{ Tabel.6 CI } \\
\hline lamdamax & 3,1114637 & 1,2235117 \\
\hline \multirow[t]{2}{*}{$\mathrm{CI}$} & 0,0557319 & 0,9163867 \\
\hline & & 0,9715653 \\
\hline \multicolumn{3}{|c|}{$\Downarrow$} \\
\hline CR & I/IR & 089 \\
\hline
\end{tabular}

Pada tabel 6, Apabila $\mathrm{CI}=0$, maka hierarki konsisten, apabila $C R<0,1$, maka hierarki cukup konsisten, apabila $\mathrm{CR}>0,1$, maka hierarki sangat tidak konsisten

\section{Contoh Pengujian}

1. Pertama masuk ke menu Crew untuk menambahkan data baru dengan nama crew, Mujafar, Iman, Musakkir dapat terlihat seperti tabel 7.:

Tabel.7 Daftar Crew

\begin{tabular}{llllll}
\hline no & id & nama & no hp & email & aksi \\
\hline 1 & crw & Mujafar & 08135 & mujafa & | edit \\
& 001 & & 32963 & r@gma & | hapus \\
& & & 2 & il.com & \\
2 & crw & Iman & 08135 & iman@ & | edit \\
& 002 & & 52550 & gmail. & | hapus \\
& & & 6 & com & \\
3 & crw & Musakk & 08524 & musak & | edit \\
& 003 & ir & 26979 & kir@g & | hapus \\
& & & 95 & mail.c & \\
& & & & om & \\
\hline
\end{tabular}

Pada tabel daftar crew dapat dilihat dari id_crew, nama_crew, no_hp, dan email terisikan dengan baik dari seorang pelaut tersebut.

2. Jika $\mathrm{CI}=0$, maka perkembangannya stabil, tampak terlihat pada tabel 8.

Tabel.8. Nilai CI\& CR

\begin{tabular}{lllll}
\hline no & kriteria & tujuan & bobot & aksi \\
\hline 1 & medical & medical & 1 & |edit \\
2 & medical & rotasi & 3 & | edit \\
3 & rotasi & sertifikasi & 0,2 & | edit \\
4 & sertifikasi & medical & 5 & |edit \\
\hline
\end{tabular}

Jika CR> 0.1, maka urutan rantai kepentingan sangat bertentangan. Artinya jika hierarki sudah konsisten, maka mulai dari perhitungan baris, kolom, 
nilai eigen, CI dan CR akan terakumulasi secara otomatis.

3. Peneliti menerangkan sub kriteria dengan penilaian yang lebih spesifik dan mendalam terhadap tiga kriteria dengan parameter tersebut tampak terlihat pada tabel 9 .

Tabel.9Sub Kriteria

\begin{tabular}{|c|c|c|c|c|}
\hline no & kode & nama & kriteria & aksi \\
\hline 1 & skr001 & $\begin{array}{l}\text { apakah pada } \\
\text { dokumen } \\
\text { kesehatan } \\
\text { terdapat } \\
\text { pemeriksaan } \\
\text { haemothology? }\end{array}$ & medical & $\begin{array}{l}\text { | detail } \\
\text { |edit } \\
\text { | hapus }\end{array}$ \\
\hline 2 & skr002 & $\begin{array}{l}\text { apakah pada } \\
\text { dokumen } \\
\text { kesehatan } \\
\text { terdapat } \\
\text { pemeriksaan } \\
\text { serology? }\end{array}$ & medical & $\begin{array}{l}\text { | detail } \\
\text { | edit } \\
\text { | hapus }\end{array}$ \\
\hline 3 & skr003 & $\begin{array}{l}\text { apakah pada } \\
\text { dokumen } \\
\text { kesehatan } \\
\text { terdapat } \\
\text { pemeriksaan } \\
\text { biochemistry? }\end{array}$ & medical & $\begin{array}{l}\text { | detail } \\
\text { | edit } \\
\text { | hapus }\end{array}$ \\
\hline 4 & skr004 & $\begin{array}{l}\text { apakah pada } \\
\text { dokumen } \\
\text { kesehatan } \\
\text { terdapat } \\
\text { pemeriksaan } \\
\text { urinalysis? }\end{array}$ & medical & $\begin{array}{l}\text { | detail } \\
\text { |edit } \\
\text { | hapus }\end{array}$ \\
\hline
\end{tabular}

\section{Keterangan:}

a. SKR001: Apakah pada dokumen kesehatan terdapat pemeriksaan haemothology? dengan kriteria kesehatan.

b. SKR002: Apakah pada dokumen kesehatan terdapat pemeriksaan serology? dengan kriteria kesehatan.

c. SKR003: Apakah pada dokumen kesehatan terdapat pemeriksaan biochemistry? dengan kriteria kesehatan.

d. SKR004: Apakah pada dokumen kesehatan terdapat pemeriksaan urinalysis? dengan kriteria kesehatan.

4. Selanjutnya masuk ke menu Alternatif dari aplikasi tersebut. Tampak terlihat pada tabel 10.

Tabel.10 Menu Alternatif.

\begin{tabular}{lllll}
\hline no & kode & nama & posisi & aksi \\
\hline s1 & alt001 & Mujafar & ch.engineer & |edit \\
& & & & $\mid$ hapus \\
2 & alt002 & Iman & master & $\begin{array}{l}\text { |edit } \\
\text { | hapus }\end{array}$
\end{tabular}

$\begin{array}{lllll}3 & \text { alt003 } & \text { Musakkir ch.engineer } & \text { | edit } \\ & \text { |hapus } \\ 4 & \text { alt004 Elmond master } & \text { | edit } \\ & & & \text { hapus }\end{array}$

Alternatif sebagai pilihan dari beberapa pelaut yang bisa diberangkatkan berdasarkan nilai kriterianya dan subkriteria tertentu.

5. Pilih kolom Penilaian pada tabel alternatif untuk menunjukkan terpenuhi atau tidak terpenuhi suatu nilai berdasarkan pada nilai kriteria yang ada pada kesehatan seperti pada tabel 11 .

Tabel.11 Penilaian.

\begin{tabular}{ll}
\hline penilaian & nilai \\
\hline apakah pada dokumen kesehatan & | terpenuhi \\
terdapat pemeriksaan & | tidak \\
haemothology? & terpenuhi \\
apakah pada dokumen kesehatan & | terpenuhi \\
terdapat pemeriksaan serology? & | tidak \\
& terpenuhi \\
apakah pada dokumen kesehatan & | terpenuhi \\
terdapat pemeriksaan biochemistry? & | tidak \\
& terpenuhi \\
\hline
\end{tabular}

- Apakah pada dokumen kesehatan terdapat pemeriksaan haemothology? dengan kriteria kesehatan $=$ Terpenuhi atau Tidak Terpenuhi.

- Apakah pada dokumen kesehatan terdapat pemeriksaan serology? dengan kriteria kesehatan $=$ Terpenuhi atau Tidak Terpenuhi.

- Apakah pada dokumen kesehatan terdapat pemeriksaan biochemistry? dengan kriteria kesehatan $=$ Terpenuhi atau Tidak Terpenuhi.

6. Jika penilaian sudah terpenuhi dengan baik, maka perhitungan ranking secara otomatis akan terakumulasi berurutan, dapat disimak dari tabel 12.

Tabel.12 Ranking Pelaut. [18]

\begin{tabular}{lllllll}
\hline $\begin{array}{c}\text { n } \\
\mathbf{0}\end{array}$ & $\begin{array}{c}\text { nam } \\
\mathbf{a}\end{array}$ & $\begin{array}{c}\text { posis } \\
\mathbf{i}\end{array}$ & $\begin{array}{c}\text { medic } \\
\text { al }\end{array}$ & rotasi & $\begin{array}{c}\text { sertifi } \\
\text { kat }\end{array}$ & $\begin{array}{c}\text { ran } \\
\text { kin } \\
\boldsymbol{g}\end{array}$ \\
\hline 1 & Luth & bosun & $120 / 12$ & $8 / 8=$ & $15 / 15$ & 1 \\
& er & & $0=1$ & 1 & $=1$ & \\
2 & Muj & ch.en & $97 / 130$ & $9 / 21$ & $17 / 32$ & 0,56 \\
& afar & ginee & $=0,746$ & $=0,42$ & $=0,531$ & 4 \\
& & $r$ & & 9 & & \\
3 & Mus & ch.en & $12 / 130$ & $6 / 21$ & $8 / 32=$ & 0,22 \\
& akki & ginee & $=0,092$ & $=0,28$ & 0,250 & 3 \\
& r & $r$ & & 6 & &
\end{tabular}




\begin{tabular}{llllll}
4 Upi & ch.en & $21 / 130$ & $6 / 21$ & $7 / 32=$ & 0,21 \\
ginee & $=0,162$ & $=0,28$ & 0,219 & 3 \\
& $r$ & & 6 & & \\
\hline
\end{tabular}

Dari Tabel.12 seorang pelaut Luther Tando tidak memiliki lawan yang diadu, maka ranking tersebut adalah 1. Apabila ada lawannya maka akan terkalkulasi secara otomatis dengan yang lain.

\section{Implementasi Sistem}

Gambar 7. adalah hasil dari pembahasan dan implementasi yang berupa tampilan halaman Login. Kapasitas login untuk dapat masuk ke dalam framework aplikasi pilihan AHP, pada halaman login, pelaut harus memiliki akun terlebih dahulu kemudian masuk dengan memasukkan nama klien dan kunci rahasia. Berikut adalah tampilan halaman login.

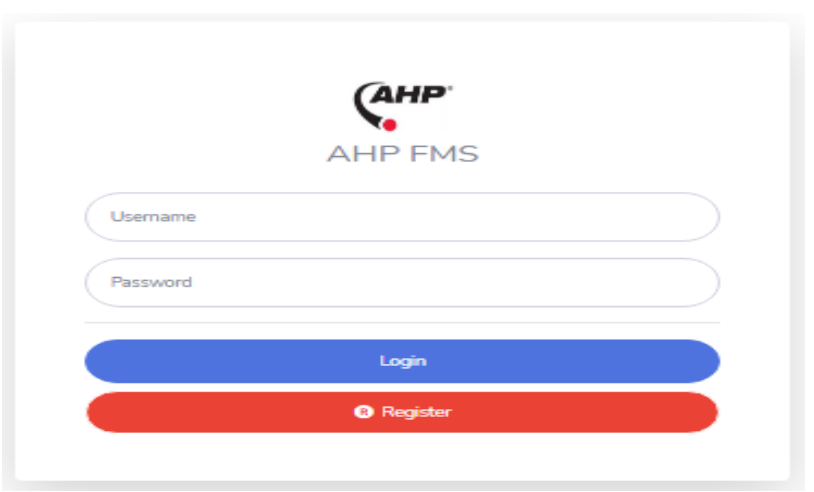

Gambar 7. Form Login

Admin dilindungi dengan access level dilakukan dengan dua cara yaitu dengan super administrator dan member. Admin dengan level super, pada saat itu dia bisa membuka semua halaman, dapat disimak seperti gambar 8 .

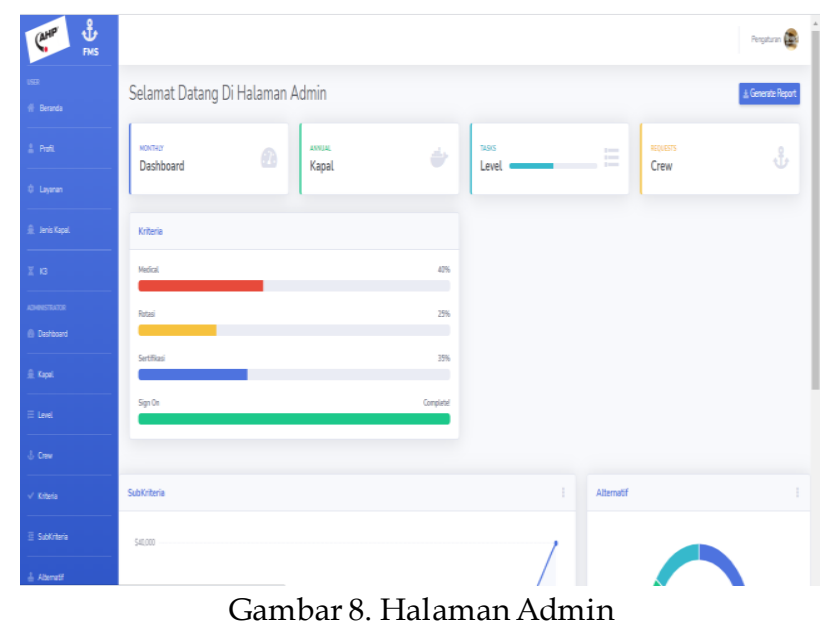

Kemudian dengan level member, hanya bisa mengakses halaman pengguna saja dan dapat dilihat gambar 9.:

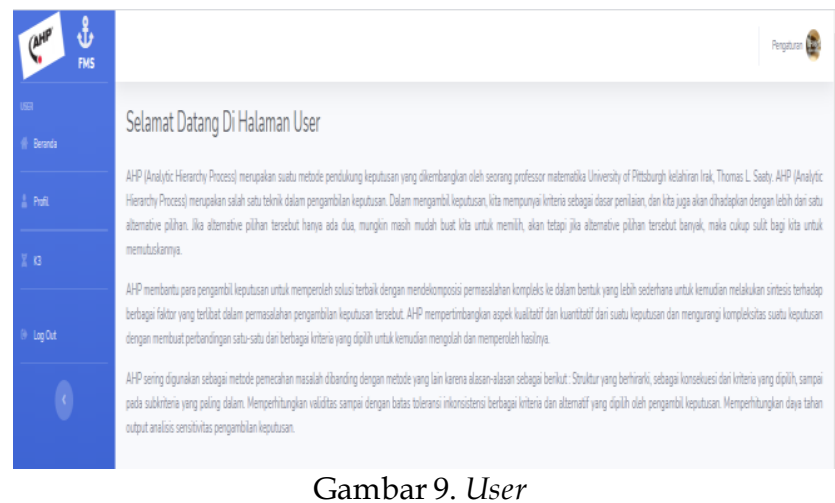

\section{Pendaftaran}

Form Pendaftaran digunakan untuk mendaftarkan diri pelaut agar memiliki akun pada aplikasi keberangkatan pelaut. Gambar 10 menunjukkan tampilan halaman pendaftaran.

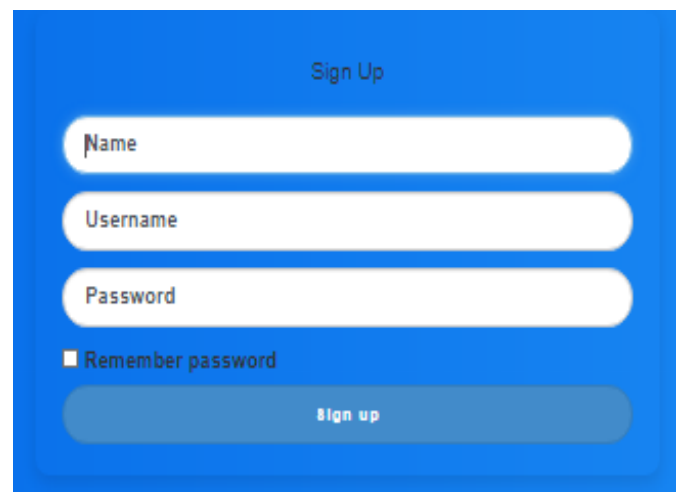

Gambar 10. Form Pendaftaran

\section{Halaman Level}

Untuk level ini adalah posisi yang bisa diisi oleh pelaut. Sebagai acuan untuk filter ranking dan kalkulasi alternatif. Tabel 13 menunjukkan level.

\begin{tabular}{lll}
\multicolumn{3}{c}{ Tabel.13 Level Pelaut. } \\
\hline no & kode & nama \\
\hline 1 & L-001 & master \\
2 & L-002 & ch.officer \\
3 & L-003 & $2^{\text {nd }}$ off \\
4 & L-004 & ch.engineer \\
5 & L-005 & $2^{\text {nd }}$ engineer \\
\hline
\end{tabular}

Untuk level ini adalah posisi yang bisa diisi oleh pelaut. Sebagai acuan untuk filter ranking dan kalkulasi alternatif.

\section{Sub Kriteria}

Sub kriteria lebih menjelaskan penilaian yang spesifik dari faktor kriteria serta dapat disimak dari sistem aplikasi seperti gambar 11 . 

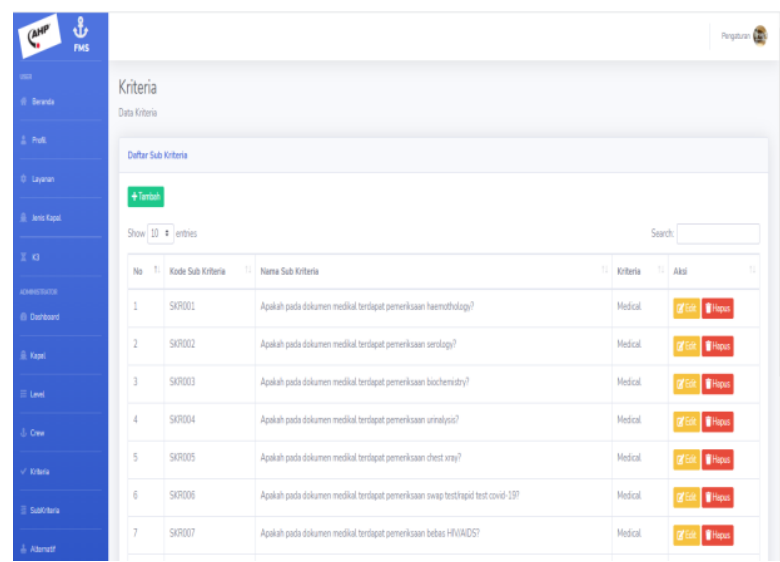

Gambar 11. Sub Kriteria

Dari gambar.11 dapat diberitahukan kriteria dari medical yang berisi tentang pemeriksaan haemotholog, serology, biochemistry untuk perlengkapan dokumen dalam keberangkatan pelaut tersebut.

\section{Alternatif}

Alternatif lebih menjelaskan tentang hasil dari kriteria mulai dari kesehatan, rotasi, sertifikasi sampai dengan perhitungan ranking dalam mengambil keputusan. Gambar 12 adalah tampilan halaman alternatif.

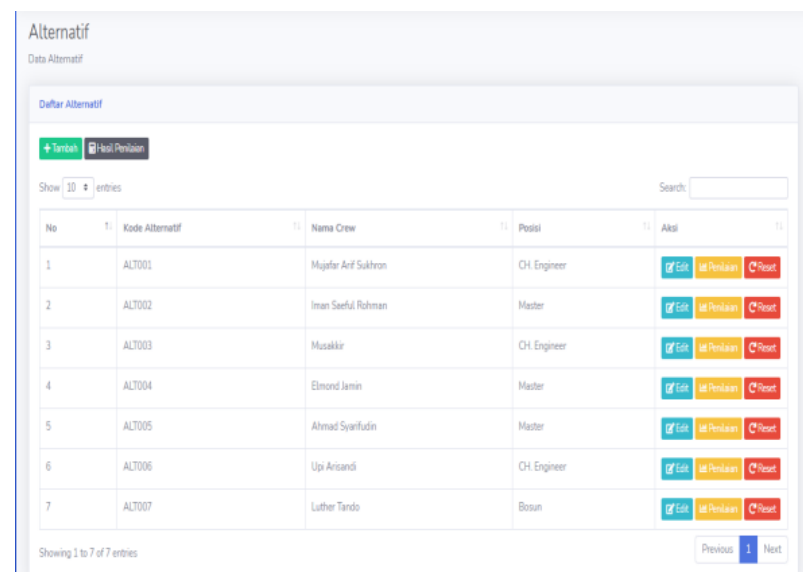

Gambar 12. Daftar Alternatif

Pada tabel diatas dapat disimak Mujafar dengan alternatif 1, Iman dengan alternatif 2, Musakkir dengan alternatif 3, serta Elmond dengan alternatif 4 . Hasil lengkap berupa pdf dan scan barcode dari alternatif hasil dan dapat dilihat digambar 13.

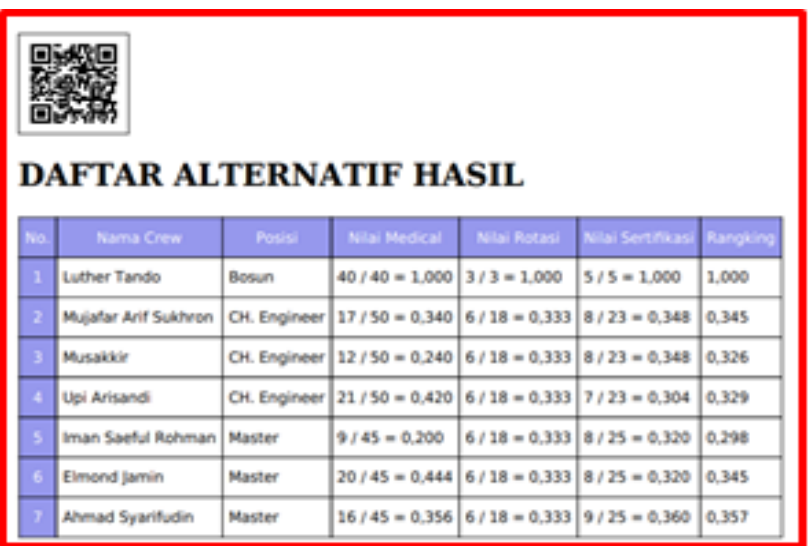

Gambar 13. Sub Kriteria

Pada gambar.13 hasil perhitungan AHP didapatkan 4 kriteria dengan 4 alternatif dan diperoleh 4 urutan nilai tertinggi, yaitu Luther dengan $1 \%$, Mujafar dengan 0,564\%, Musakkir dengan $0,223 \%$, Upi dengan 0,213\%.

\section{KeSIMPULAN}

Kesimpulan dari adanya aplikasi keberangkatan pelaut berbasis web ini adalah mengimplementasikan algoritma AHP (analytic hierarchy process) untuk menentukan keputusan apakah diterima maupun tidak dalam keberangkatan pelaut dalam Fast Offshore Supply dalam berbasis web. Merancang aplikasi untuk pelaut berbasis web yang bertujuan untuk mempermudah pelaut dalam memberikan laporan pekerjaan yang awalnya bersifat manual, menjadi ke komputerisasi atau serba digital. Berdasarkan pelaksanaan aplikasi, menemukan proposal untuk perbaikan aplikasi yang harus dimungkinkan dalam pemeriksaan tambahan. Kerangka tersebut dapat dibentuk menjadi lebih baik lagi dengan mengikuti perkembangan yang ada.

\section{UCAPAN TERIMA KASIH}

Untuk semua pertemuan yang memberi kenyamanan dan kritik yang mendukung, Selama pemeriksaan, khususnya para perintis dan pekerja Fast Offshore Supply Jakarta Barat.

\section{DAFTAR PUSTAKA}

[1] Novrisal, D., Almira, F. and Febrianty, E. (2019) 'Pemilihan Prioritas Program Kerja Dengan Menggunakan Metode Analytical Hierarchy Process Pada Pt. Garuda Indonesia Cargo', Jurnal Logistik Indonesia, 3(1), pp. 1-9. doi: 10.31334/jli.v3i1.346.

[2] Pramono, P. P., Fahrianto, F. and Sc, M. (2019) 'Pendeteksian Dini Tingkat Kemanan Informasi Berbasis Iso 27001 : 2013 Menggunakan Metode AHP ( Analytical Hierarchy Process )', 2(2), pp. 57-64. 
[3] Bintoro, Ketut B. Y. Et Al. (2018) 'Sistem Penunjang Keputusan Tujuan Wisata Air Terjun di Kota Bogor Menggunakan Metode $\mathrm{AHP}^{\prime}$, SinkrOn; Vol 2 No 2 (2018): Call Paper Volume 2 Nomor 2 April 2018, 2(April 2018), pp. 164-171. Available at: http://jurnal.polgan.ac.id/index.php/sinkron /article/view/114.

[4] Rifqi, M. And Wardhani, N. (2017) 'Aplikasi Peran Dan Kegunaan Teknologi Near Field Communication (Nfc) Terhadap Kegiatan Proses Belajar Mengajar Di Perguruan Tinggi', Jurnal Ilmu Teknik dan Komputer, 1(1), pp. 20 26. doi: 10.22441/jitkom.

[5] R Laisouw, A., Lutfi, S. And Tempola, F. (2019) 'Sistem Pendukung Keputusan Pemberian Bantuan Program Keluarga Harapan (Pkh) Pada Orang Miskin Di Kota Ternate Menggunakan Metode AHP', JIKO (Jurnal Informatika dan Komputer), 2(1), pp. 34-60. doi: 10.33387/jiko.v2i1.973.

[6] Agustini, F. (2018) 'Penerapan Metode AHP Pada Pemilihan Kosmetik Yang Tepat Untuk Siswi SMA', Swabumi, 6(2), pp. 165-173. doi: 10.31294/swabumi.v6i2.4577.

[7] Rachman, R. (2019) 'Penerapan Metode AHP Untuk Menentukan Kualitas Pakaian Jadi Di Industri Garment', Jurnal Informatika, 6(1), pp. 1-8. doi: 10.31311/ji.v6i1.4389.

[8] Azhar, Z. And Handayani, M. (2018) 'Analisis Faktor Prioritas Dalam Pemilihan Perumahan Kpr Menggunakan Metode AHP', Jurnal Manajemen Informatika dan Sistem Informasi, 1(2), p. 19. doi: 10.36595/misi.v1i2.38.

[9] L. Laurentinus, L. And Rinaldi, S. (2019) 'Implementasi Metode Analytical Hierarchy Process dan Simple Additive Weighting untuk Pemilihan Dosen Terbaik Studi Kasus STMIK Atma Luhur', Jurnal Teknologi Informasi dan Ilmu Komputer, 6(6), p. 655. doi: 10.25126/jtiik.2019661636.

[10] Nasution, Y. R. (2017) 'Menentukan Tingkat Kemacetan Lalulintas Dengan Metode Analytical Hierarchy Process ( AHP )', Jurnal Ilmu Komputer dan Informatika, 01(November), pp. 40-45.

[11] Arisusanty, D. J. Et Al. (2018) 'Oleh: Staf Pengajar Program Studi Teknologi Perikanan Laut, Sekolah Pascasarjana Institut', II(1), pp. 57-67.

[12] Salim, A. And Lubis, B. O. (2019) 'Pemilihan Merek Beras yang Diminati Konsumen Studi Kasus CV Beras Alami Menggunakan AHP', MATRIK?: Jurnal Manajemen, Teknik Informatika dan Rekayasa Komputer, 19(1), pp. 147-154. doi: 10.30812/matrik.v19i1.497.
[13] Azza, G. M. And Dores, A. (2018) 'Sistem Informasi Manajemen Marketing Tools Serta Penerapan Metode AHP (Analytical Hierarchy Process) Pada Proses Uji Kualitas Barang (Studi Kasus : PT Edi Indonesia)', Jurnal Cendikia, XVI, pp. 107-114.

[14] Pertiwi Hari Dini, "2018. "Metode Extreme Programming (Xp) Pada Website Sistem Informasi Franchise Lkp" Palcomtech," Jurnal Mikrotik,Vol.8,No. 1,Juli pp. 86-98.

[15] Rosiska, E. (2018) ‘Penerapan Metode Analitycal Hierarchy Process (AHP) dalam Menentukan Mitra Usaha Berprestasi', Jurnal RESTI (Rekayasa Sistem dan Teknologi Informasi), 2(2), pp. 479485. doi: 10.29207/resti.v2i2.419.

[16] Ruiz Rondan, H. S. Et Al. (2020) 'GIS-AHP MultiDecision-Criteria-Analysis For The Optimal Location Of Solar Energy Plants At Indonesia', arXiv. Elsevier Ltd, 6, pp. 3249-3263. doi: 10.1016/j.egyr.2020.11.198.

[17] In, C. And Kou, G. (2020) 'A Heuristic Method To Rank The Alternatives In The AHP Synthesis', Applied Soft Computing. Elsevier B.V., (xxxx), p. 106916. doi: 10.1016/j.asoc.2020.106916.

[18] Abdul Rojak, S. R. And Rifai, A. (2018) 'Penerapan Metode Analytical Hierarchy Process dalam Memilih Bahan Bakar Minyak untuk Kendaraan Roda Dua', Jurnal Kajian Ilmiah, 18(1), pp. 1-8. doi: 10.31599/jki.v18i1.184.

[19] Unver, S. And Ergenc, I. (2020) 'Safety Risk Identification And Prioritize Of Forest Logging Activities Using Analytic Hierarchy Process $(\mathrm{AHP})^{\prime}$, Alexandria Engineering Journal. Faculty of Engineering, Alexandria University, 60(1), pp. 1591-1599. doi: 10.1016/j.aej.2020.11.012.

[20] Ariani (2017) 'Sistem Penunjang Dalam Penentuan Prioritas Pemilihan Percetakan Media Promosi Menggunakan Metode AHP', Jurnal Informatika, 4(2), pp. 214-221.

[21] Rohandi, M., Tuloli, M. Y. and Jassin, M. R. T. (2017) 'Sistem Pendukung Keputusan dalam Penentuan Prioritas Pengembangan Kawasan Wisata Bawah Laut', Jurnal Nasional Teknik Elektro dan Teknologi Informasi (JNTETI), 6(4), pp. 2-8. doi: 10.22146/jnteti.v6i4.354.

[22] Suendri (2018) 'Implementasi Diagram UML (Unified Modelling Language) Pada Perancangan Sistem Informasi Remunerasi Dosen Dengan Database Oracle (Studi Kasus: UIN Sumatera Utara Medan)', Jurnal Ilmu Komputer dan Informatika, 3(1), pp. 1-9. Available at: http://jurnal.uinsu.ac.id/index.php/algoritma / article/download/3148/1871.

[23] Rachman, A. N. (2018) 'Sistem Informasi Wisata Di Ampera Waterpark', Jurnal Siliwangi,4(2), pp. 
T Triatmojo \& M Rifqi

Komputika: Jurnal Sistem Komputer, Vol.11, No. 1, April 2022

$87-92$.

Available

at:

http://jurnal.unsil.ac.id/index.php/jssainstek /article/download/570/369.

[24] Prasetyaningrum, P. T. (2018) ‘Rancang Bangun E-Resource Perpustakaan Menggunakan Web Service Rest', Sintak, 2(24), pp. 201-208.

[25] Bathin, M. S. And Ramayanti, D. (2019) 'SOBATHUNI: Aplikasi Rumah Sewa Berbasis Web', Jurnal Edukasi dan Penelitian Informatika (JEPIN), 5(2), p. 183. doi: 10.26418/jp.v5i2.30452. 